\title{
Computer Assisted Learning Media and Decimal Board: How it Impact on Elementary Students' Concept Mastery?
}

\author{
Helmi Rahmawati \\ Mathematics Education, Faculty of Education and Teacher Training, Universitas Qamarul \\ Huda Badaruddin, Jl. Turmuzi Badrudin, Bagu, Praya, Indonesia, 83371. \\ Corresponding Author e-mail: helmirahmawati18@gmail.com \\ Received: May 2021; Revised: June 2021; Published: June 2021
}

\begin{abstract}
The lack of students' mastery of decimal fractions has become a current issue among researchers. The comparisin of decimal fraction values was still an obstacle for students. The use of learning media in this study is the Computer Assisted Learning Media and Decimal Board can be a solution to these problems. This study aimed to describe the increase of elementary students' concept mastery on decimal fractions subject matter. Descriptive-quantitative method with pre-test and post-test was carried out to achieve the research objectives. The subjects in this study were the $4^{\text {th }}$ grade students (22 students) in the East Lombok area. The students' concept mastery was measured using a multiple-choice test instrument of 10 items. The research data were analyzed descriptively and statistically using paired sample t-test. The results showed that students' concept mastery increased after learning (pre-test: 54.5\%; post-test: 77.27\%). The results of statistical tests using the paired sample t-test also showed that students' concept mastery had increased significantly after learning ( $\mathrm{p}<$ 0.05). Based on the results of the study, it can be concluded that learning using Computer Assisted Learning Media and Decimal Boards can improve elementary school students' concept mastery on decimal fractions subject matter.
\end{abstract}

Keywords: Learning Media; Elementary Students; Concept Mastery; Decimal Fractions

How to Cite: Rahmawati, H. (2021). Computer Assisted Learning Media and Decimal Board: How it Impact on Elementary Students' Concept Mastery?. Prisma Sains : Jurnal Pengkajian Ilmu dan Pembelajaran Matematika dan IPA IKIP Mataram, 9(1), 88-94. doi:https://doi.org/10.33394/j-ps.v9i1.3963

https://doi.org/10.33394/j-ps.v9i1.3963

Copyright@ 2021, Rahmawati This is an open-access article under the CC-BY License.

\section{INTRODUCTION}

Students' understanding of learning content must be the goal and expectation of all teachers. Understanding can be created through the learning process. Learning is an active process of composing meaning through every interaction with the environment by building the relationship between the concepts already possessed with the phenomena being studied (Suyono \& Hariyanto, 2011). In order to build or understand the concept of a learning content it is necessary to have strong knowledge. According to Beetlestone (2013) knowledge is the information needed to run a task or to understand a concept.

At the end of the fourth grade, students should be able to compare the tenth and hundredth decimal digits and the reason for decimal number sizes. However, According to the U.S. Department of Education. (2011), 67\% of fourth graders couldn't estimate decimal places on the number lines in the National Assessment for Progress of Education (Malone, 2017). Then according to Rittle-Johnson, Siegler, \& Alibali, many students wrongly apply the logic of integers to decimals, for example assuming that $0.274>0.83$ for $274>83$ (Malone, 2017). According to Irwin, Putt, Resnick et al., Stacey et al., Sackur-Grisvard \& Léonard, students often have difficulty in mastering decimals and common and persistent misunderstandings, with difficulty persisting into adulthood (Adams et al., 2014) . This happens because of the lack of mastery of students' conceptions of decimal fractions. Because concept is an element of cognition that helps us simplify and summarize information 
(Santrock, 2009). So by simplifying and summarizing the information we get we can generalize the information we get by associating it with the information we already have.

Conceptual understanding is an important aspect of learning (Santrock, 2009). In many cases, conceptual understanding is enhanced when teachers explore a topic in depth and provide examples of the appropriate and interesting concepts involved. In this study, we embed a conceptual understanding of decimal fractions through the application of instructional media manuals and ICT media. Where ICT media is designed to introduce material about decimal fractions and is expected to make students interested in studying material about decimal fractions and equipped with exercise questions. While the media manual that we used was a decimal board media that aims to deepen the information conveyed through the ICT media had been put as real as possible so that no one is abstract and is expected to help students in understanding the concept of decimal fractions.

The materials in both ICT and problem-solving environments using conventional media such as decimal boards can help elementary school students to understand decimals. Learning about problem-solving environments using decimal point learning media is more focused on common misconceptions. A more general decimal rational number, this study focuses on improving children's knowledge of decimal concepts and procedures. Unfortunately students often have basic misconceptions about decimals and are struggling to apply the procedure properly especially on addition and decimal reduction (Kouba at al, 1989).

Decimal is a very difficult topic for students to master. And in fact, students' difficulties with decimals often last into adulthood. One of the reasons for this difficulty is that students have a common and persistent misunderstanding, for example students often consider decimals as "round" (eg they are 0.25 is greater than 0.8 because 25 is greater than 8 ). Such decimal misconceptions must be overcome so that students can master advanced mathematics (Glasgow, 2000).

In studying the value of the decimal place, students write numbers in the place value graph and represent the numbers in several different ways (Jhonson Bethany \& Koedinger, 2009). Putt, 1995 chose to focus on decimal calculations for several reasons. First, decimal numbering has been recognized for some time to be a significant source of learning and teaching difficulties. Many students have no understanding of the decimal value, for example, a common misconception is that students think that 0.8 is equal to 8. McLaren et al. (2017) targets four misconceptions targeted by the study material from his research. First, the longer decimal number has a larger value. For example in choosing the largest decimal number in the following sequence of numbers: $0.6754 ; 0.78 ; 0.8 ; 0.321$; of which the largest number of numbers is 0.8 . But the misconception that occurred, students think the largest is the longest that is 0.6754 .

The second misconception is that students think the shorter decimal numbers have greater value. For example in sorting the decimal numbers from the largest to the smallest, as in sorting the numbers $0.1 ; 0.890 .333 ; 0.2214$. In order to sort that number many students think that the shorter number is the larger number. So the students order the largest to the smallest being: $0.2214 ; 0.333 ; 0.89 ; 0.1$. While the correct answer is $0.89 ; 0.333 ; 0.2214 ; 0.1$.

Then for the third misconception is the number that is on the left and on the right of the decimal point apart or has its own value. For example in summing $34.53+3.5$. Error results obtained by students is 37.103 or 37.58 . For result 37,103 got student from student instantly add 34 with 3 so yield 37. Then in summing number at right of coma that is 53 with 5, student add 5 with 5 so produce 10, then lower number 3 so that yield 103. This happened because students assume that the value of a number separated by a comma on a decimal number has its own value. For the results of 37.58 obtained students by adding $34+3=37$ and $53+5=58$ obtained by aligning the number 3 with 5 then lower the number 5 to obtain 58.

The fourth misconception is that students consider decimal numbers less than 1.0 to be less than 0 . Students assume that if a decimal number starts from a digit 0 before a comma in 
decimal, that means the number is less than 0 . For example, such as $0.23<0$. The aims of this study was to find decimal fractions, sort and compare decimal fractions, summarize and subtract decimal fractions, and solve problems related to decimal fractions. This research describes the decimal fractions in which it contains some items of competence, matter, and practice questions (Figure 1).

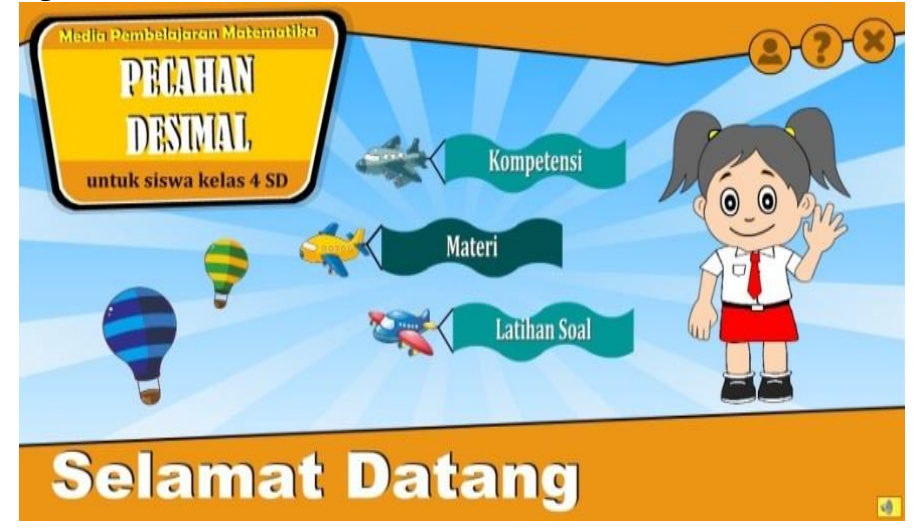

Figure 1. Decimal fraction media display

In the competence there are some that will be discussed in it first, these competencies, basic competencies, and indicators. in the competence contains some goals that must be achieved by students in understanding the concept of decimals (Figure 2). In the material discussed, in which is how the students can know the location of decimal placement starting from one tenth, one hundredth, one thousandth, tenth of thousands, one hundredth of a thousand and so on (Figure 3).

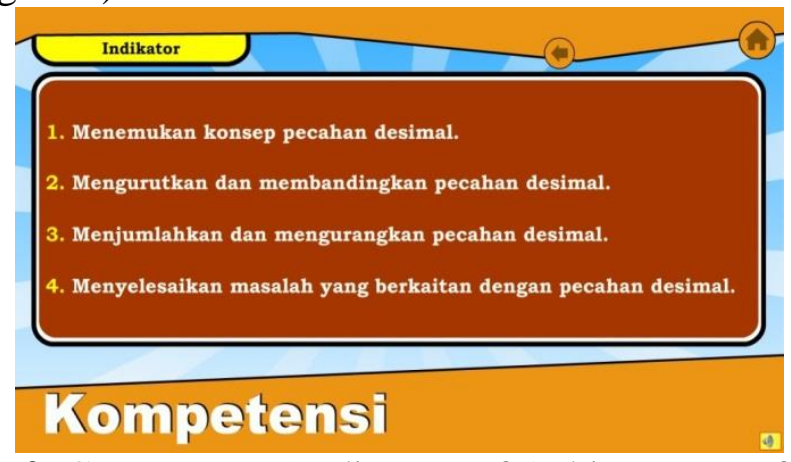

Figure 2. Competence (Indicators of Achievement of Goals)

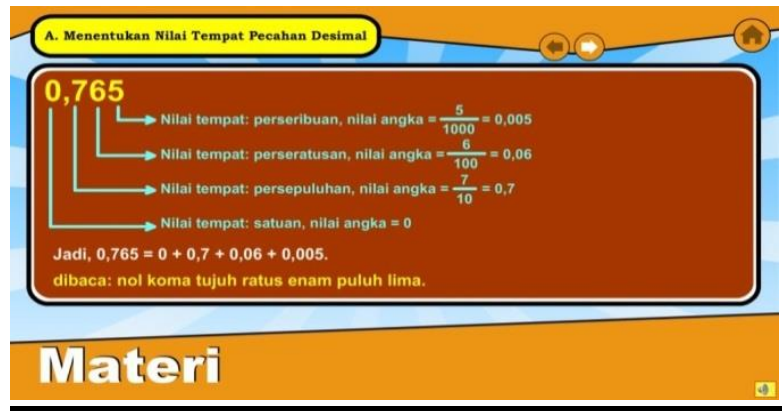

Figure 3. Matter

While the exercise questions in it contains 10 questions that will be done by students when the students have understood the concept of decimal either from decimal placement, or addition and decimal reduction operations (Figure 4). 


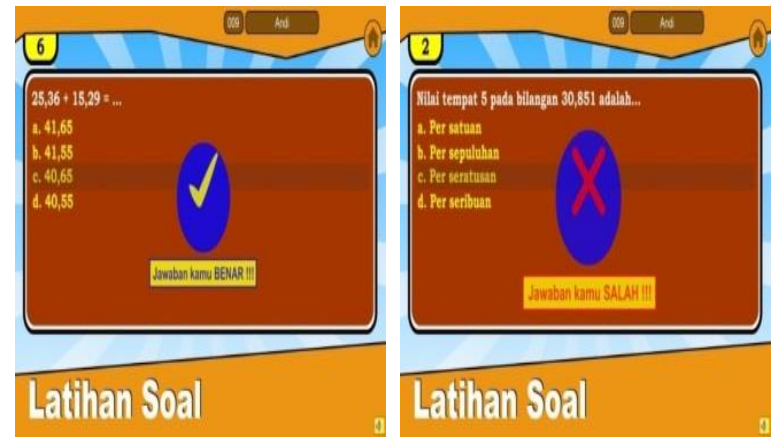

Figure 4. Exercises

In the exercise of the question if the student answers correctly it will be given a description by saying that your answer is correct, but if the student's answer is wrong then it will be given also a description that your answer is wrong (Figure 4). The instructional media in this study uses decimal board where the decimal board will explain about the placement of decimal number. In this decimal board there are 13 columns. Where the columns determine the place value in the decimal which consists of unit value, tens, hundreds, thousands, tens of thousands, hundreds of thousands, millions, one tenth, one hundredths, one thousandth , and so on. The value of the unit in the middle is the 7 th column. For values above 1 are to the left of the unit place value. While the value of place below 1 is to the right of the unit place value.

In this decimal board (Figure 5), there are several formations and quantity readings starting from the blocks present in standard decimal board colors known by the students. The student already knew that the purple color was the unit, the yellow color for the tithe, and the color red for hundredth. Once the student has understood then invite the student to form a quantity on the board using the box and ask him to read it. For example, "give 2 units for one tenth, 3 units for one hundred, and 2 units for one thousandth ". Once you are sure you are mastered by the student ask the student to form the decimal using the card provided.
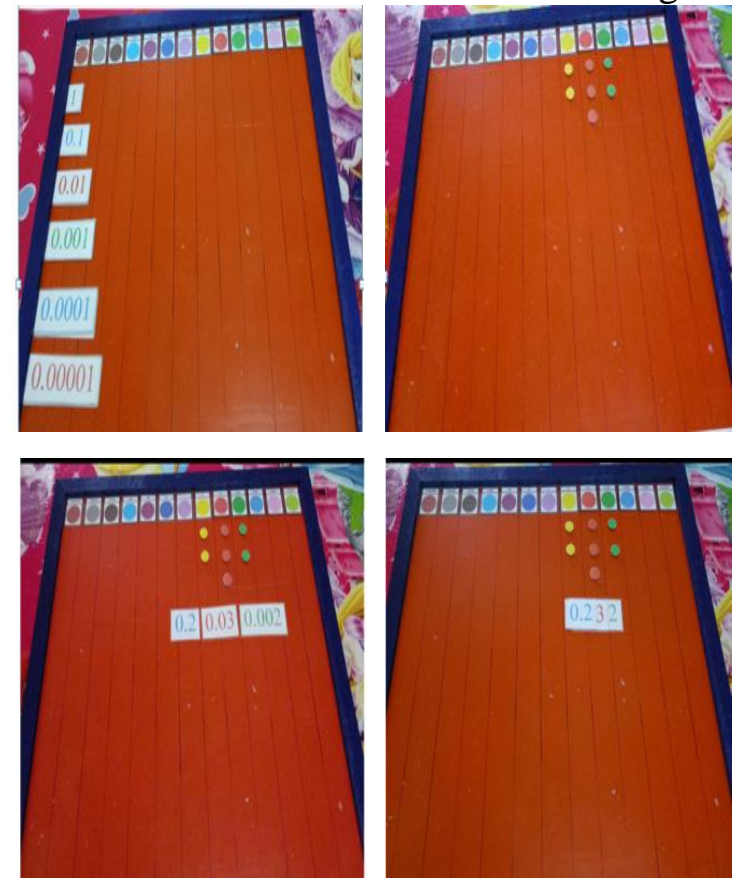

Figure 5. Decimal Board

We build on this concept and then discuss the fact that the whole decimal number is. We also teach about how to sum and subtract decimals using those boards. There are enough things to be gained in terms of skill, and understanding the concept of decimal with this decimal board. We are looking forward to recommending it to students who need a faster way to understand decimal concepts. 


\section{METHOD}

The type of this research is quantitative research. This research was conducted in one of the primary schools located in Suradadi, East Lombok. The subjects of the study were class 4 elementary school in academic year 2019/2020 which amounted to 22 students, consisting of 12 male students and 10 female students.

The study was conducted in elementary school grade 4 using math lesson during 3 hours lesson (105 minutes). The research begins with a pretest which consists of 10 items and is given 15 minutes to do it. After that continued with the provision of material on ICT media for \pm 20 minutes. After giving the material using ICT media, continued using manual media that is decimal board for \pm 30 minutes. Furthermore, it will be followed by the exercise of the problems that exist on ICT media which is done for \pm 20 minutes. After giving the exercise about we give post-test consisting of 10 items. the problem in the post-test has the same characteristics as the problem on the pretest. Problem post-test done for \pm 15 minutes.

\section{RESULTS AND DISCUSSION}

To see the results of pretest and post-test data analysis can be seen in Table 1 below.

Table 1. Analysis of Pretest and Postes Data

\begin{tabular}{lrrr}
\hline & \multicolumn{2}{c}{ Prestest } \\
\hline N $\quad$ Valid & 22 & 22 \\
\cline { 2 - 4 } \multicolumn{1}{c}{ Missing } & 0 & 0 \\
\hline Mean & 60.36 & 72.59 \\
Median & 66.00 & 75.00 \\
Mode & 70 & 75 \\
Std. Deviation & 16.200 & 12.366 \\
Variance & 262.433 & 152.920 \\
Range & 59 & 45 \\
Minimum & 30 & 50 \\
Maximum & 89 & 95 \\
\hline Sum & 1328 & 1597 \\
\hline
\end{tabular}

Based on Table 1 above, it can be seen that the average of pretest value is 60,36. While the average post-test value is 72.59 . Then in the post-test, the lowest score obtained by the research subjects is 30 , while the post-test is 50 . Furthermore the highest score obtained by students on pretest is 89 and the post-test is 95 . So it can be concluded that for the average value of students on pretest and post-test increased from 60.36 to 72.59 . Likewise with the lowest value in pretest to post-test progressed from 30 to 50 . Then for the highest value also increased that is on the pretest is 89 and the post-test is 95 .

The research hypothesis conducted in this study describe as below.

$H_{0}=$ Learning Media can not improve the understanding of elementary students in understanding the concept of decimal fractions.

$H_{1}=$ Learning Media can improve the understanding of elementary students in understanding the concept of decimal fractions.

Statistically can be written as follows.

$\mathrm{H}_{0}: \mu_{\text {Pre }}=\mu_{\text {Post }}$

$\mathrm{H}_{1}: \mu_{\text {Pre }}<\mu_{\text {Post }}(*)$

Research Hypothesis at $\mathrm{H}_{1}$ 
Because the samples are tied together, the result analysis uses Paired-Samples T Test. Here is a table of results of hypothesis analysis using Paired-Samples T Test presented in the Table 2 below.

Table 2. Paired Samples Test

\begin{tabular}{|c|c|c|c|c|c|c|c|c|c|}
\hline & & \multicolumn{5}{|c|}{ Paired Differences } & \multirow[b]{3}{*}{$\mathrm{t}$} & \multirow[b]{3}{*}{ df } & \multirow[b]{3}{*}{ Sig. (2-tailed) } \\
\hline & & \multirow[b]{2}{*}{ Mean } & \multirow{2}{*}{$\begin{array}{c}\text { Std. } \\
\text { Deviation }\end{array}$} & \multirow{2}{*}{$\begin{array}{l}\text { Std. Error } \\
\text { Mean }\end{array}$} & \multicolumn{2}{|c|}{$\begin{array}{l}95 \% \text { Confidence } \\
\text { Interval of the } \\
\text { Difference }\end{array}$} & & & \\
\hline & & & & & Lower & Upper & & & \\
\hline$\overline{\text { Pair } 1}$ & pre - post & -12.227 & 16.512 & 3.520 & -19.548 & -4.906 & -3.473 & 21 & .002 \\
\hline
\end{tabular}

Based on SPSS Output, the results obtained are: $t_{\text {count }}=-3.473$; Sig. 2-tailed $=0.002$; $\frac{1}{2}$ Sig. 2-tailed $=0.001$; and $\alpha=0,05$. Because $t_{\text {count }}<0$ and $1 / 2$ Sig. 2-tailed $<\alpha$, then is $H_{0}$ rejected, so the research hypothesis is accepted. This means that the use of learning media can improve students' understanding of decimal fractions.

Based on the results of research conducted by McLaren et al. (2017), mathematics learning with computer-based games is better than using conventional learning. In contrast to our research results, we use ICT mathematics learning media and conventional learning media (decimal boards) to test how students understand about decimal fractions. Our results show that the student's posttest score significantly increases more than the pretest score.

We hope that in order to improve students' understanding of decimal fractions, it is necessary to add time for the use of instructional media in the form of ICT and conventional learning media, because considering the steps of using ICT learning media and conventional learning media presented so complicated. Another important finding is that students do not have the initial knowledge of decimal fractions this is seen from the pretest value obtained, so in fact the students get a low score on the pretest. If students who score low on pretest are not treated using ICT and conventional learning media then the student will experience many mistakes.

There are some potential issues with the results we've discussed and discussed here. First, students are not assigned randomly, because practical constraints in conducting studies at school, undertaking studies at school, are different from the laboratory. Because students may be disturbed by their friends who are learning with other, more interesting material. We provide materials for all students in the class, rather than giving individually, under certain conditions. However, we address this issue by (a) viewing the classroom conditions corresponding to the performance levels reported by the teacher and (b) seeing that students are in class condition with students in two relatively balanced conditions in terms of sex and age. Second, we found that his condition differed significantly in pretest and posttest when treated. Based on the results of the significant analysis of students with posttest score has a higher average score.

Of course, the important question to ask is why the post-test score is better than the pretest value? To answer this question, it is important to identify the instructional medium used. As has been explained in the ICT learning media in which contains several items describing the decimal fractions of competence, matter, and exercise questions (Figure 1). The more complex and simple design of learning media used in this study had an impact on good learning outcomes. Some items are competence, material, and practice questions (Figure 1).

In the competence there are some that will be discussed in it first, these competencies, basic competencies, and indicators. in the competence contains some goals that must be achieved by students in understanding the concept of decimals (Figure 2). In the material 
discussed in it is how the students can know the location of placement decimal placement starting from the tithe, hundredths, the sovereignty, the tenth, the percentage and so on.

Students play ICT learning media and conventional media for decimal boards for several minutes instead of at once. And this also provides benefits for students so that students can operate the learning media well and can make the students better understand the decimal fractions in question. Based on the research hypothesis that we do it turns out students can understand decimal fractions with the given material with the help of learning media.

\section{CONCLUSION}

Based on the research finding, it can be concluded that learning using Computer Assisted Learning Media and Decimal Boards can improve elementary school students' concept mastery on decimal fractions subject matter. In addition, using conventional media in the form of decimal boards and ICT media can make students more active in learning proccess.

\section{RECOMMENDATION}

The use of learning media is very important to be integrated in learning. This study only focuses on decimal fractions, so it is necessary to carry out research on other materials to obtain consistency in the effectiveness of using learning media in the future.

\section{ACKNOWLEDGMENT}

This research received no specific grant from any funding agency in the public,commercial, or not-for-profit sectors.

\section{REFERENCES}

Adams, D. M., McLaren, B. M., Durkin, K., Mayer, R. E., \& Rittle-Johnson, B. (2014). Using erroneous examples to improve mathematics learning with a web-based tutoring system. Computers in Human Behavior, 36, 401-411.

Beetlestone, B. (2013). CREATIVE LEARNING: Strategi Pembelajaran untuk Melesatkan Kreatifitas Siswa. Bandung: Nusa Media.

Glasgow, R., Ragan, G., Fields, W. M., Reys, R., \& Wasman, D. (2000). The decimal dilemma. Teaching Children Mathematics, 7(2), 89-93.

Jhonson, B \& Koedinger. (2009). Iterating between lessons on concepts and procedures can improve mathematics knowledge. British Journal of Educational Psychology, 79, 483-500.

Kouba, V. L., Carpenter, T. P., \& Swafford, J. O. (1989). Number and operations. In M. M. Lindquist (Ed.), Results from the Fourth Mathematics Assessment of the National Assessment of Educational Progress (pp. 64-93). Reston, VA: National Council of Teachers of Mathematics, Inc.

Malone, A. S., Loehr, A. M., \& Fuchs, L. S., (2017). The role of domain-general cognitive abilities and decimal labels in at-risk fourth-grade students' decimal magnitude understanding. Learning and Individual Differences, 1041-6080.

Putt, I. J. (1995). Preservice teachers ordering of decimal numbers: When more is smaller and less is larger! Focus on Learning Problems in Mathematics, 17(3), 1-15.

Santrock, J. W. (2009). Psikologi pendidikan: educational psychology. (2 ${ }^{\text {nd }}$ Edition, Buku 2). Jakarta: Salemba Humanika.

Suyono \& Hariyanto. (2011). Belajar dan Pembelajaran. Bandung: Remaja Rosdakarya. 